\author{
A randomized trial of bevacizumab for newly \\ diagnosed glioblastoma \\ Gilbert MR, Dignam JJ, Armstrong TS i wsp. \\ N Engl J Med 2014; 370: 699-708
}

\begin{abstract}
Obecnym standardem leczenia nowo rozpoznanego glejaka wielopostaciowego jest jednoczesna radiochemioterapia z temozolomidem z kontynuacją leczenia temozolomidem. Bewacyzumab, humanizowane przeciwciało monoklonalne przeciw śródbłonkowemu czynnikowi wzrostu naczyń typu A, jest stosowany w leczeniu nawrotów glejaka wielopostaciowego. Nie wiadomo, czy dodanie bewacyzumabu wpływa na wyniki leczenia pierwszej linii.
\end{abstract}

Metody. Do randomizowanego kontrolowanego placebo badania z zastosowaniem podwójnie ślepej próby włączano chorych z nowo rozpoznanym, potwierdzonym centralnie glejakiem wielopostaciowym. Stosowano radioterapię (60 Gy) w połączeniu z podawanym codziennie temozolomidem. Leczenie bewacyzumabem lub placebo rozpoczynano w trakcie czwartego tygodnia radioterapii i kontynuowano przez 12 cykli leczenia podtrzymującego. W przypadku progresji ujawniano informację o rodzaju stosowanego leczenia i podejmowano decyzję o rozpoczęciu lub kontynuacji leczenia bewacyzumabem. Punktami końcowymi badania było: stwierdzenie 25-procentowego obniżenia ryzyka zgonu oraz 30-procentowego obniżenia ryzyka progresji lub zgonu związanych z podaniem bewacyzumabu.

Wyniki. W badaniu zarejestrowano 978 chorych, 637 poddano randomizacji. Nie stwierdzono znamiennej różnicy w czasie przeżycia pomiędzy chorymi otrzymującymi bewacyzumab i placebo (mediana odpowiednio 15,7 i 16,1 miesięcy; współczynnik ryzyka zgonu w grupie leczonej bewacyzumabem 1,13). Czas do progresji był dłuższy w grupie otrzymującej bewacyzumab (10,7 vs 7,3 miesięcy; współczynnik ryzyka progresji lub zgonu 0,79 ). Odnotowano niewielki wzrost częstości występowania nadciśnienia, zdarzeń związanych z chorobą zakrzepowo-zatorową, perforacji jelit oraz neutropenii w grupie otrzymującej bewacyzumab.W grupie tej obserwowano również większe nasilenie występowania objawów, gorszą jakość życia oraz pogorszenie funkcji poznawczych.

Wnioski. Zastosowanie bewacyzumabu w pierwszej linii leczenia nie wydłużyło czasu całkowitego przeżycia chorych na nowo rozpoznanego glejaka wielopostaciowego. Wydłużenie czasu do progresji nie osiągnęło założonego progu.

\author{
Bevacizumab plus radiotherapy-temozolomide \\ for newly diagnosed glioblastoma \\ Chinot OL, Wick W, Mason W i wsp. \\ N Engl J Med 2014; 370: 709-722
}

Obecnym standardem leczenia nowo rozpoznanego glejaka wielopostaciowego jest radioterapia $z$ temozolomidem. W niniejszym badaniu III fazy oceniono wpływ dodania bewacyzumabu do radioterapii z temozolomidem na wyniki leczenia.

Metody. Chorych na glejaka wielopostaciowego w lokalizacji nadnamiotowej przydzielano losowo do leczenia bewacyzumabem (10 mg/kg iv co 2 tygodnie) lub placebo, w połączeniu z radioterapią ( $60 \mathrm{~Gy} / 30 \mathrm{fr}$ ) oraz doustnym temozolomidem ( $75 \mathrm{mg} / \mathrm{m}^{2}$ codziennie przez 6 tygodni). Po 28-dniowej przerwie kontynuowano leczenie podtrzymujące: bewacyzumab (10 mg/kg iv co 2 tygodnie) lub placebo, w połączeniu z temozolomidem ( 150 do $200 \mathrm{mg} / \mathrm{m}^{2} \mathrm{przez}$ 5 dni co 4 tygodnie), po 6 cyklach chorzy otrzymywali wyłącznie bewacyzumab ( $15 \mathrm{mg} / \mathrm{kg}$ iv co 3 tygodnie) lub placebo. Leczenie kontynuowano do progresji lub wystąpienia nieakceptowalnych działań niepożądanych. Końcowymi punktami badania był oceniany przez badaczy czas do progresji oraz czas całkowitego przeżycia.

Wyniki. 458 chorych leczono bewacyzumabem, 463 otrzymywało placebo. Mediana czasu do progresji w grupie otrzymującej bewacyzumab była dłuższa niż w grupie otrzymującej placebo (10,6 vs 6,2 miesiąca; stratyfikowany współczynnik ryzyka progresji lub zgonu, 0,64; $95 \%$ przedział ufności 0,55 do 0,74; $p<0,001$ ). Korzyść obserwowano we wszystkich podgrupach. Nie stwierdzono różnic w czasie całkowitego przeżycia (stratyfikowany współczynnik ryzyka zgonu, 0,88; 95\% przedział ufności, 0,76 do 1,$02 ; p=0,10$ ). Udział chorych przeżywających rok w grupie leczonej bewacyzumabem i placebo wyniósł odpowiednio $72,4 \%$ oraz $66,3 \%(p=0,049)$, natomiast 2 lata $-33,9 \%$ oraz $30,1 \%$ $(p=0,24)$. Wyjściowa jakość życia oraz stan sprawności były dłużej utrzymane wśród chorych otrzymujących bewacyzumab. Mieli oni również niższe zapotrzebowanie na sterydy. U większej liczby chorych leczonych bewacyzumabem w porównaniu z grupą leczoną placebo stwierdzono działania niepożądane w stopniu trzecim lub wyższym $(66,8 \%$ vs 51,3\%); działania niepożądane w stopniu trzecim lub wyższym często były związane ze stosowaniem bewacyzumabu (32,5\% vs $15,8 \%)$. 
Wnioski. Dodanie bewacyzumabu do radioterapii z temozolomidem nie wydłuża przeżycia chorych na glejaka wielopostaciowego. W porównaniu z placebo czas do progresji oraz wyjściowa jakość życia były lepsze wśród chorych otrzymujących bewacyzumab, jednak w grupie tej częściej występowały działania niepożądane.

\section{Improved survival with bevacizumab in advanced cervical cancer}

Tewari KS, Sill MW, Long HJ i wsp.

N Engl J Med 2014; 370: 734-743

Śródbłonkowy czynnik wzrostu naczyń (VEGF) pobudza angiogenezę i jest mediatorem progresji raka szyjki macicy. Bewacyzumab, humanizowane przeciwciało anty-VEGF, wykazuje aktywność u chorych z progresją po uprzednim leczeniu. Większość chorych z nawrotem raka szyjki macicy otrzymywała uprzednio cisplatynę z radioterapią, co ogranicza skuteczność cisplatyny w leczeniu nawrotu. Oceniono skuteczność bewacyzumabu w skojarzeniu z wielolekową chemioterapią niezawierającą pochodnych platyny u chorych na nawrotowego lub rozsianego raka szyjki macicy.

Metody. W badaniu 2x2 factorial design 452 chore przydzielono losowo do chemioterapii z bewacyzumabem w dawce $15 \mathrm{mg} / \mathrm{kg}$ lub do wyłącznej chemioterapii. Zastosowane schematy chemioterapii składały się z cisplatyny w dawce $50 \mathrm{mg} / \mathrm{m}^{2}$ z paklitakselem w dawce $135 \mathrm{lub} 175 \mathrm{mg} / \mathrm{m}^{2}$; topotekanu w dawce $0,75 \mathrm{mg} / \mathrm{m}^{2}$ w dniach 1 .-3. w połączeniu z paklitakselem $175 \mathrm{mg} / \mathrm{m}^{2}$ w dniu 1. Cykle powtarzano co 21 dni do progresji, stwierdzenia nieakceptowanych działań niepożądanych lub uzyskania całkowitej remisji choroby. Oceniano czas całkowitego przeżycia, jako klinicznie znamienne przyjęto 30-procentowe obniżenie współczynnika ryzyka zgonu.

Wyniki. Badane grupy nie różniły się znamiennie pod względem wieku, rozpoznania histopatologicznego, stanu sprawności, uprzedniego leczenia z zastosowaniem platyny oraz stopnia zaawansowania. Wyniki leczenia topotekanem z paklitakselem nie były lepsze od wyników leczenia cisplatyną z paklitakselem (współczynnik ryzyka zgonu 1,20). We wspólnej analizie danych chorych leczonych różnymi schematami chemioterapii stwierdzono, że dodanie bewacyzumabu wiązało się z wydłużeniem czasu przeżycia ( 17,0 vs 13,3 miesięcy; współczynnik ryzyka zgonu 0,71 ; 98\% przedział ufności 0,54 do 0,95; $p=0,004$ w teście jednostronnym) oraz wyższym udziałem odpowiedzi na leczenie ( $48 \%$ vs $36 \%, p=0,008$ ). Leczenie bewacyzumabem w porównaniu z wyłączną chemioterapią wiązało się z częstszym występowaniem nadciśnienia w stopniu $\geq 2$. ( $25 \%$ vs $2 \%)$, zdarzeń zakrzepowo-zatorowych w stopniu $\geq 3$. (8\% vs 1\%) oraz przetok jelitowych $w$ stopniu $\geq 3$. (3\% vs $0 \%$ ).
Wnioski. Dodanie bewacyzumabu do chemioterapii u chorych na raka szyjki macicy z nawrotem, rozsiewem lub chorobą przetrwałą po uprzednim leczeniu wiązało się z wydłużeniem mediany czasu przeżycia o 3,7 miesiąca.

\section{Gy versus 24 Gy radiotherapy for patients with indolent lymphoma (FORT): a randomised phase 3 non-inferiority trial}

Hoskin P, Kirkwood A, Popowa B i wsp.

Lancet Oncol 2014; 15: 457-463

Chłoniak grudkowy jest wrażliwy na niskie dawki promieniowania jonizującego. W badaniu porównano odpowiedź chłoniaka grudkowego na zastosowanie dawki 4 Gy w 2 frakcjach oraz dawki 24 Gy w 12 frakcjach.

Metody. W prospektywnym otwartym badaniu III fazy typu non-inferiority z losowym doborem chorych porównano skuteczność radioterapii w dawce 4 Gy w 2 frakcjach ze standardową dawką 24 Gy w 12 frakcjach. Do badania włączono chorych na chłoniaka grudkowego lub chłoniaka strefy brzeżnej w wieku > 18 lat, poddawanych radykalnej lub paliatywnej radioterapii, nieleczonych w miesiącu poprzedzającym włączenie do badania. Pierwotnym punktem końcowym był czas do miejscowej progresji, oceniany zgodnie z intencją leczenia. Obszary tarczowe radioterapii przydzielano losowo (w stosunku 1:1) metodą minimizacji, stratyfikując względem histologii (chłoniak grudkowy vs chłoniak strefy brzeżnej), intencji leczenia (paliatywna lub radykalna) oraz ośrodka leczącego.

Wyniki. W okresie od 7 kwietnia 2006 roku do 8 czerwca 2011 roku w 43 brytyjskich ośrodkach 299 obszarów tarczowych przydzielono losowo do napromieniania dawką 24 Gy, zaś 315 - do napromieniania dawką 4 Gy. Po medianie czasu obserwacji 26 miesięcy $(0,39-75,4)$ odnotowano 91 miejscowych progresji (21 w grupie napromienianej dawką 24 Gy i 70 w grupie napromienianej dawką 4 Gy). Czas do miejscowej progresji chorych napromienianych dawką $4 \mathrm{~Gy}$ był krótszy w porównaniu z napromienianymi dawką 24 Gy (nie spełniono kryterium równoważności - współczynnik ryzyka [HR] 3,42, 95\% przedział ufności [Cl] 2,09-5,55, $\mathrm{p}<0,0001)$. Wczesne działania niepożądane w 3. i 4. stopniu nasilenia obserwowano u 8 spośród 282 (3\%) chorych napromienianych dawką 24 Gy oraz 4 spośród 300 (1\%) — napromienianych dawką 4 Gy. U 4 chorych (1\%) w grupie napromienianych dawką 24 Gy oraz u 4 (1\%) napromienianych dawką 4 Gy odnotowano późne działania niepożądane. Najczęstszym działaniem niepożądanym w grupie chorych napromienianych dawką 24 Gy było zapalenie jamy ustnej (w 3. stopniu nasilenia; 2 chorych z wczesnym zapaleniem jamy ustnej oraz 2 z późnym zapaleniem jamy ustnej). W grupie chorych napromienianych dawką 4 Gy nie odnotowano 
żadnego przypadku zapalenia jamy ustnej. Najczęściej występującym wczesnym działaniem niepożądanym był ból okolicy napromienianej (w 3. stopniu nasilenia; 2 chorych napromienianych dawką 4 Gy oraz 1 chory napromieniany dawką 24 Gy). Najczęstszym późnym działaniem niepożądanym było zmęczenie (w 3. stopniu nasilenia; 2 chorych napromienianych dawką 4 Gy oraz 1 chory napromieniany dawką 24 Gy).

Wnioski. Zastosowanie dawki 24 Gy w 12 frakcjach w leczeniu chorych na chłoniaki o niskim stopniu złośliwości jest skuteczniejszym schematem frakcjonowania radioterapii i powinno być standardem postępowania. Zastosowanie dawki 4 Gy pozostaje użytecznym schematem paliatywnej radioterapii.

\section{Risk-adapted targeted intraoperative radiotherapy versus whole-breast radiotherapy for breast cancer: 5-year results for local control and overall survival from the TARGIT-A randomised trial}

Vaidaya J, Wenz F, Bulsara M i wsp.

Lancet 2014; 383: 603-613

W badaniu TARGIT-A u chorych na raka piersi porównano śródoperacyjną radioterapię w pojedynczej dawce, dostosowaną do oszacowanego ryzyka (TARGIT), z frakcjonowaną radioterapią wiązką zewnętrzną. Przedstawiono 5-letnie wyniki dotyczące kontroli miejscowej oraz pierwszą analizę całkowitego przeżycia.

Metody. W badaniu TARGIT-A typu non-inferiority chore na inwazyjnego przewodowego raka piersi $\geq 45$. roku życia przydzielano losowo w stosunku 1:1 do TARGIT lub napromieniania całej piersi wiązką zewnętrzną, stratyfikując blokowo względem ośrodka leczącego oraz czasu realizacji radioterapii śródoperacyjnej. Przydział losowy wykonywano przed wycięciem zmiany w piersi (przed oceną histopatologiczną materiału pooperacyjnego; TARGIT skojarzony z wycięciem zmiany) lub po wycięciu zmiany (po ocenie histopatologicznej materiału pooperacyjnego;TARGIT przy rewizji loży pooperacyjnej). Chore przydzielone do TARGIT otrzymywały teleradioterapię (wyłączając dodawkowanie loży pooperacyjnej), jeśli w ostatecznym badaniu histopatologicznym wykazano dodatkowe czynniki ryzyka. Pierwotnym punktem końcowym była bezwzględna różnica w miejscowych nawrotach w zachowanej piersi, przy wstępnie określonym marginesie równoważności wynoszącym 2,5\% w ciągu 5 lat. Wtórnymi punktami końcowymi były powikłania leczenia oraz umieralność.

Wyniki. Chore włączano do badania od 24 marca 2000 do 25 czerwca 2012 roku w 33 ośrodkach w 11 krajach. 1721 chorych przydzielono losowo do TARGIT, zaś 1730 - do teleradioterapii. Napromienianie wiązką zewnętrzną było konieczne u 15,2\% [239 spośród 1 571] chorych, które otrzymały TARGIT (21,6\% przed oceną histopatologiczną, 3,6\% - po ocenie histopatologicznej). Mediana czasu obserwacji 3451 chorych wyniosła 2 lata i 5 miesięcy (IQR 12-52 miesięcy), 2020 chorych - 4 lata, a 1222 chorych - 5 lat. 5-letnie ryzyko miejscowego nawrotu w zachowanej piersi wyniosło 3,3\% (95\% Cl 2,1-5,1) dla TARGIT w porównaniu $z 1,3 \%(0,7-2,5)$ dla teleradioterapii $(p=0,042)$. Skuteczność TARGIT (przed oceną histopatologiczną, $n=2298$ ) była zbliżona do teleradioterapii: $2,1 \%(1,1-4,2)$ w porównaniu z 1,1\% (0,5-2,5; $p=0,31)$. Różnice pomiędzy grupami wyniosły powyżej 2,5\% (TARGIT 5,4\% [3,0-9,7] vs EBRT 1,7\% $[0,6-4,9] ; p=0,069)$ w przypadku opóźnionego zastosowania TARGIT (po ocenie histopatologicznej, $n=1153$ ). Umieralność $z$ powodu raka piersi była zbliżona $w$ badanych grupach $(2,6 \%[1,5-4,3]$ dla TARGIT vs $1,9 \%[1,1-3,2]$ dla teleradioterapii; $p=0,56)$. Wykazano znamiennie mniejszą liczbę zgonów z przyczyn niezwiązanych z rakiem piersi w grupie chorych poddanych TARGIT $(1,4 \%[0,8-2,5]$ vs 3,5\% $[2,3-5,2] ; p=0,0086)$, co wynika ze zmniejszenia liczby zgonów z przyczyn sercowo-naczyniowych oraz z powodu innych nowotworów. Umieralność wyniosła 3,9\% $(2,7-5,8)$ dla TARGIT w porównaniu z 5,3\% $(3,9-7,3)$ dla teleradioterapii $(p=0,099)$. Częstość występowania powikłań dotyczących rany pooperacyjnej była podobna, jednak powikłania skórne w 3. i 4. stopniu nasilenia były obserwowane znamiennie rzadziej w grupie poddanej TARGIT (4 spośród 1720 vs 13 spośród $1731, \mathrm{p}=0,029$ ).

Wnioski. Śródoperacyjna radioterapia w pojedynczej dawce w skojarzeniu z wycięciem zmiany, z uwzględnieniem ryzyka nawrotu, powinna być opcją rozważaną jako alternatywa dla pooperacyjnej teleradioterapii w grupie starannie wybranych chorych na raka piersi, spełniających kryteria włączenia do badania TARGIT-A.

\section{Efficacy of HPV-based screening for prevention of invasive cervical cancer: follow-up of four European randomised controlled trials}

Ronco G, Dillner J, Elfstrom M i wsp.

Lancet 2014; 383: 524-532

W 4 badaniach klinicznych z losowym doborem chorych porównano badania przesiewowe w kierunku raka szyjki macicy, oparte na wykrywaniu wirusa HPV, z badaniem cytologicznym. Punktem końcowym badań było wykrycie stanu przednowotworowego. Jak dotąd nie oszacowano względnej skuteczności badań przesiewowych wykrywających wirusa HPV w porównaniu ze standardowo stosowanym badaniem cytologicznym w zapobieganiu inwazyjnemu rakowi szyjki macicy w populacji kobiet poddawanych regularnym badaniom kontrolnym ani nie uwzględniono wpływu zmiennych, np. wieku chorych i czasu trwania kon- 
troli. Przeprowadzono analizę 4 badań z losowym doborem chorych, podsumowując ich wyniki.

Metody. W badaniach: szwedzkim - Swedescreen, holenderskim — POBASCAM, brytyjskim - ARTISTIC i włoskim - NTCC, 176464 kobiet w wieku od 20 do 64 lat przydzielono losowo do badań przesiewowych w kierunku raka szyjki macicy opartych na wykrywaniu wirusa HPV (ramię eksperymentalne) lub badaniu cytologicznym (ramię kontrolne). Mediana czasu obserwacji wyniosła 6,5 roku (1 214415 osobolat). Wykryto 107 inwazyjnych raków szyjki macicy, wykorzystując badania przesiewowe, badania histopatologiczne oraz rejestry nowotworów. Obliczono wskaźniki zachorowalności na inwazyjnego raka szyjki macicy (skumulowany i odnoszący się do warunków badania — ramię eksperymentalne vs kontrolne).

Wyniki. Wskaźnik zachorowalności na inwazyjnego raka szyjki macicy wśród kobiet od momentu włączenia do badania do końca okresu obserwacji wyniósł 0,60 (95\% Cl 0,40-0,89). Skuteczność obu metod badań przesiewowych w wykrywaniu inwazyjnego raka szyjki macicy była zbliżona w okresie pierwszych 2,5 roku obserwacji $(0,79,0,46-1,36)$, ale potem była znamiennie niższa $w$ ramieniu eksperymentalnym $(0,45,0,25-0,81)$. W grupie kobiet $z$ ujemnym wynikiem testu przesiewowego przy włączaniu do badania wskaźnik zachorowalności wyniósł 0,30 (0,15-0,60). Skumulowany współczynnik zachorowalności na inwazyjnego raka szyjki macicy $w$ grupie kobiet $z$ ujemnym wynikiem wstępnego testu wyniósł w ramieniu eksperymentalnym 4,6 na $105(1,1-12,1)$ i 8,7 na $105(3,3-18,6)$ po odpowiednio 3,5 oraz 5,5 roku; natomiast $\mathrm{w}$ ramieniu kontrolnym - 15,4 na $105(7,9-27,0)$ oraz 36,0 na 105 (23,2-53,5). Współczynniki zachorowalności nie różniły się w zależności od stopnia zaawansowania klinicznego choroby, ale były niższe dla gruczolakoraków $(0,31,0,14-0,69)$ w porównaniu z rakami płaskonabłonkowymi $(0,78,0,49-1,25)$. Współczynnik zachorowalności był najniższy w populacji kobiet w wieku 30-34 (0,36, 0,14-0,94).

Wnioski. Badania przesiewowe, wykrywające wirusa HPV, o 60-70\% skuteczniej zapobiegają inwazyjnym postaciom raka szyjki macicy w porównaniu z badaniem cytologicznym. Dane z badań klinicznych z losowym doborem chorych uzasadniają rozpoczęcie badań przesiewowych wykrywających wirusa HPV od 30. roku życia i ich powtarzanie przynajmniej co 5 lat.

\section{Liverpool Care Pathway for patients with cancer in hospital: a cluster randomised trial}

Costantini M, Romoli V, Di Leo Silvia i wsp.

Lancet 2014; 383: 226-237

Jakość opieki nad chorymi na nowotwory złośliwe umierającymi w szpitalach i ich rodzinami pozostaje niezadowa- lająca. Podjęto próbę wprowadzenia najlepszych rozwiązań opieki hospicyjnej do warunków szpitalnych, opracowując algorytm UK Liverpool Care Pathway (LCP) dla chorych w stanie terminalnym. Skuteczność algorytmu LCP zbadano we włoskich szpitalach, oceniając poprawę jakości opieki nad hospitalizowanymi w terminalnym stanie choroby nowotworowej oraz nad ich rodzinami.

Metody. W pragmatycznym, klasterowym badaniu klinicznym z losowym doborem chorych 16 włoskich oddziałów internistycznych przydzielono losowo do wdrażania algorytmu LCP-I lub standardowej opieki. Dla każdego z oddziałów oceniano opiekę nad chorymi, którzy zmarli z powodu nowotworu w okresie ostatnich 3 miesięcy przed randomizacją (przed interwencją) i w okresie 6 miesięcy po zakończeniu programu szkoleniowego LCP-I. Pierwotnym punktem końcowym była całościowa ocena jakości opieki. Analizę przeprowadzono zgodnie $z$ intencją leczenia.

Wyniki. Po wdrożeniu programu szkoleniowego zebrano dane o 308 chorych, którzy zmarli z powodu nowotworu (147 na oddziałach korzystających z algorytmu LCP-I i 161 na oddziałach kontrolnych). Przeprowadzono rozmowę z 232 (75\%) spośród 308 członków rodziny, 119 (81\%) spośród 147, których bliscy przebywali w oddziałach wdrażających LCP-I (średnia wielkość grupy 14,9 [8-22]) i 113 (70\%) spośród 161 przebywających w oddziałach kontrolnych (14,1 [8-22]). Po wdrożeniu programu LCP-I nie wykazano znamiennej różnicy w skali całościowej jakości opieki pomiędzy oddziałami korzystającymi z algorytmu LCP-I a oddziałami kontrolnymi (70,5/100 vs 63,0 /100; średnia różnica 7,6 [95\% $\mathrm{Cl}-3,6$ do 18,7]; $\mathrm{p}=0,186)$.

Wnioski. W omawianym badaniu wykazano mniejszą skuteczność algorytmu LCP-I niż w przeprowadzonych uprzednio badaniach II fazy. Jeśli program jest realizowany właściwie, może potencjalnie zmniejszyć różnicę w jakości opieki pomiędzy hospicjum a szpitalem. Potrzebne są dalsze badania w celu określenia, które składowe programu LCP-I są skuteczne w poprawie jakości opieki szpitalnej nad terminalnymi chorymi oraz ich rodzinami.

\section{Fluorouracil-based adjuvant chemotherapy after preoperative chemoradiotherapy in rectal cancer: long-term results of the EORTC 22921 randomised study}

Bosset J, Calais G, Mineur L i wsp.

Lancet Oncol 2014; 15: 184-190

W badaniu EORTC 22921 oceniano skuteczność dodania przedoperacyjnej lub pooperacyjnej chemioterapii do przedoperacyjnej radioterapii $w$ grupie chorych na raka odbytnicy. Po medianie czasu obserwacji 5 lat wykazano, że chemioterapia — niezależnie od czasu zastosowania —znamiennie poprawiła kontrolę miejscową. Zastosowanie 
uzupełniającej chemioterapii nie wydłużyło czasu przeżycia, ale krzywe Kaplana-Meiera oddaliły się od siebie, sugerując możliwość opóźnionej korzyści. Przedstawiono dojrzałe wyniki badania.

Metody. Chorych na operacyjnego raka odbytnicy (cT3-4) przydzielono losowo do przedoperacyjnej radioterapii bez chemioterapii lub w skojarzeniu z chemioterapią, a następnie do uzupełniającej chemioterapii lub do obserwacji. Przydział losowy przeprowadzono metodą minimizacji z uwzględnieniem: ośrodka leczącego, płci, cechy $T$ oraz odległości guza od brzegu odbytu. Teleradioterapię na obszar miednicy stosowano w dawce 45 Gy w 25 frakcjach przez 5 tygodni. Każdy cykl chemioterapii składał się z fluorouracylu ( $350 \mathrm{mg} / \mathrm{m}^{2} / \mathrm{d}$ w krótkim wlewie dożylnym) oraz kwasu folinowego (leukoworyna $20 \mathrm{mg} / \mathrm{m}^{2} / \mathrm{d}$ w krótkim wlewie dożylnym). Przedoperacyjna chemioterapia składała się z 2 cykli (w trakcie 1.i 5. tygodnia radioterapii). Podawano 4 cykle uzupełniającej chemioterapii co 3 tygodnie. Pierwotnym punktem końcowym był czas całkowitego przeżycia. Analizę przeprowadzono zgodnie z intencją leczenia.

Wyniki. Od kwietnia 1993 do marca 2003 roku 1011 chorych przydzielono losowo do leczenia, w tym 252 do przedoperacyjnej radioterapii i 253 do każdej z pozostałych trzech grup. Po medianie czasu obserwacji, która wyniosła 10,4 roku (IQR 7,8-13,1), udział 10-letnich całkowitych przeżyć w grupie poddanej przedoperacyjnej radioterapii wyniósł 49,4\% (95\% Cl 44,6-54,1), a w grupie chorych poddanej przedoperacyjnej chemioradioterapii - 50,7\% (45,9-55,2; [HR 0,99, 95\% Cl $0,83-1,18 ; p=0,91])$. 10-letnie przeżycie całkowite w grupie chorych otrzymujących uzupełniającą chemioterapię wyniosło 51,8\% (95\% Cl 47,0-56,4), a w grupie chorych poddanych obserwacji - 48,4\% (43,6-53,0; [HR 0,91, 95\% Cl 0,77-1,09, $\mathrm{p}=0,32$ ). 10-letnie przeżycie wolne od choroby wyniosło
$44,2 \%(95 \% \mathrm{Cl} 39,5-48,8)$ w grupie chorych poddanych przedoperacyjnej radioterapii i 46,4\% $(41,7-50,9)$ w grupie chorych poddanych przedoperacyjnej radiochemioterapii (HR 0,93, 95\% Cl 0,79-1,10; p = 0,38). Udział 10-letnich przeżyć wolnych od choroby wyniósł 47,0\% $(95 \%$ Cl 42,2-51,6) w grupie chorych otrzymujących uzupełniającą chemioterapię i 43,7\% $(39,1-48,2)$ w grupie chorych poddanych obserwacji (HR 0,91, 95\% Cl 0,77-1,08, p = 0,29). 10-letni skumulowany wskaźnik wystąpienia wznowy miejscowej wyniósł 22,4\% (95\% Cl 17,1-27,6) w grupie chorych poddanych wyłącznej radioterapii, 11,8\% $(7,8-15,8)$ w grupie chorych poddanych indukcyjnej radiochemioterapii, 14,5\% $(10,1-18,9)$ w grupie chorych napromienianych i poddanych uzupełniającej chemioterapii, a $11,7 \%(7,7-15,6)$ w grupie chorych poddanych indukcyjnej i uzupełniającej chemioterapii ( $p=0,0017)$. Nie obserwowano różnic w skumulowanych wskaźnikach wystąpienia przerzutów odległych $(p=0,52)$. Późne działania niepożądane występowały jednakowo często we wszystkich 4 grupach badanych $(p=0,22)$. Wnioski. Zastosowanie uzupełniającej chemioterapii z udziałem fluorouracylu po przedoperacyjnej radioterapii (wyłącznej lub skojarzonej z chemioterapią) nie wpływa na przeżycie wolne od choroby ani na przeżycie całkowite. Wyniki przedstawionego badania nie uzasadniają stosowania uzupełniającej chemioterapii po przedoperacyjnej chemioradioterapii lub wyłącznej przedoperacyjnej radioterapii. Potrzebne są strategie oparte o nowe schematy indukcyjnej chemioterapii.

\author{
Opracowali: \\ Dr n. med. Anna Kowalczyk \\ Dr n. med. Ewa Szutowicz \\ Lek. med. Anna Wrona \\ Dr n. med. Krzysztof Konopa
}

